\title{
A INFORMAÇÃO MEDIADA NO DISCURSO DE EDIR MACEDO: ANÁLISE DE EDITORIAIS DA FOLHA UNIVERSAL
}

\section{LA INFORMACIÓN MEDIADA EN EL HABLA MACEDO EDIR: ANÁLISIS DE LOS EDITORES DE HOJA DE UNIVERSAL}

\author{
Ciro Athayde Barros Monteiro* \\ Oswaldo Francisco de Almeida Junior**
}

\begin{abstract}
RESUMO
Introdução: A informação mediada no discurso de Edir Macedo mantém-se em posição de destaque frente às transformações da sociedade contemporânea. O estudo se propôs a analisar as estratégias utilizadas em seu discurso para mediar informação por meio dos editoriais da Folha Universal (FU), jornal da Igreja Universal do Reino de Deus (IURD). Objetivo: Conhecer as estratégias discursivas utilizadas por Edir Macedo no sentido de compreender como essa informação é mediada e de que forma consegue ampliar sua influência cotidianamente transformando-o em um dos principais mediadores do Brasil. Metodologia: Foram selecionados quatro editoriais do jornal escritos entre 2009 e 2011, com uso da metodologia da Análise de Discurso.

Resultados: Os editoriais analisados demonstram que o bispo utiliza-se prioritariamente do discurso persuasivo para conseguir adesão do público apelando quase sempre à função emotiva e o modo imperativo. Conclusões: Destacou-se a necessidade da $\mathrm{Cl}$ de compreender esse discurso, já que essa informação é responsável por influenciar um número amplo de pessoas fazendo com que a IURD, a cada dia, consiga ampliar o seu espaço na imprensa e na sociedade.
\end{abstract}

Palavras-chave: Edir Macedo. Mediação da Informação. Análise do Discurso. Folha Universal.

\footnotetext{
*Doutorando do Programa de Pós-Graduação em Ciência da Informação da Universidade Estadual Paulista (Unesp/Marília). E-mail: cirocosmos@gmail.com

**Doutor em Ciência da Informação pela Escola de Comunicação e Artes da Universidade de São Paulo (USP). Professor do Programa de Pós-Graduação em Ciência da Informação da Universidade Estadual Paulista (Unesp/Marília). E-mail: ofaj@ofaj.com.br
} 


\section{INTRODUÇÃO}

Pensar a ciência e suas problemáticas vinculadas à informação, o conhecimento, e principalmente a sociedade, aparece como essencial para tentar compreender as influências dos aspectos religiosos na constituição da nossa concepção de ciência e de pesquisa. A partir dos pressupostos e problemáticas sociais passamos a compreender o nascimento e a justificativa para o desenvolvimento de uma pesquisa científica que deve ser necessariamente social, já que o conhecimento e a realidade são socialmente construídos (BERGER; LUCKMANN, 1985).

Esse pensar cotidianamente sobre a informação, um dos objetos de pesquisa da Ciência da Informação $(\mathrm{Cl})$, e seu funcionamento na sociedade nos trouxe as seguintes problemáticas: o que as pessoas leem? Quais são as principais fontes de acesso à informação da sociedade? Ao observarmos o uso dos suportes informacionais em cidades do interior de São Paulo, percebemos que mesmo com a enorme adesão da sociedade ao aparelho celular, o jornal Folha Universal e os livros de autoria de Edir Macedo continuam sendo amplamente lidos. O bispo tem mais de 30 livros publicados.

Por meio da problemática de querer compreender a informação mediada no discurso de Edir Macedo, que vem ganhando poder e espaço nos principais meios de comunicação do país, desenvolvemos a presente pesquisa. $\mathrm{A} \mathrm{Cl}$ tem a necessidade de gerenciar a informação entre as diversas áreas do conhecimento e conta com técnicas muito bem definidas de registro, armazenamento, organização e disseminação da informação. No entanto, não se sabe ao certo o que é esta ciência e do que se ocupa exatamente, além de não alcançar consenso entre os autores, tampouco uma definição que seja universalmente aceita. É caracterizada, principalmente, pela diversidade de abordagens, por enfoques teórico-conceituais variados e por se movimentar em um terreno multifacetado, como afirma Lenia Pinheiro:

Informação é tradicionalmente relacionada a documentos impressos e a bibliotecas, quando de fato a informação de que trata a Ciência da Informação, tanto pode estar num diálogo entre cientistas, em comunicação informal, numa inovação para indústria, em patente, numa fotografia ou objeto, no registro 
magnético de uma base de dados ou em biblioteca virtual ou repositório, na internet. Todos os campos do conhecimento alimentam-se de informação, mas poucos são aqueles que as tomam como objeto de estudo e este é o caso da Ciência da Informação. Por outro lado, esta informação de que trata a Ciência da Informação movimenta-se num terreno multifacetado, tanto pode ser informação numa determinada área quanto sob determinada abordagem (PINHEIRO, 2004, p.32).

Todavia restringir o conceito de $\mathrm{Cl}$ a apenas alguns campos do conhecimento frente às inúmeras transformações do mundo moderno, pode ser prejudicial a esta área e a sua necessidade de dialogar com outras ciências, como já relatava Le Coadic na década de 1990, afirmando que:

A Ciência da Informação é uma dessas novas interdisciplinas, um desses novos campos do conhecimento onde colaboram entre si, principalmente, a psicologia, a linguística a sociologia, a informática, a matemática, a lógica, a estatística, a eletrônica, a economia, o direito, a filosofia, a política $\mathrm{e}$ as telecomunicações (LE COADIC, 1996, p. 22).

O próprio Le Coadic, pesquisador que prioriza a informação registrada como objeto de pesquisa da $\mathrm{Cl}$, já admitia há duas décadas a necessidade da $\mathrm{Cl}$ dialogar com as múltiplas áreas do conhecimento. Essa perspectiva, que dá prioridade a informação registrada como objeto de pesquisa, torna a $\mathrm{Cl}$ um campo restrito a apenas um tipo de informação. Dessa forma, é necessário que a $\mathrm{Cl}$ passe a se preocupar com a informação mediada na sociedade de forma que possa receber contribuições das múltiplas disciplinas para compreender seu objeto.

Nesse sentido, o estudo acerca da informação veiculada pela IURD surge como um importante filão a ser pesquisado dentro da $\mathrm{Cl}$. Entendemos como Informação Religiosa toda e qualquer informação que esteja vinculada a algum tipo de manifestação religiosa direta ou indiretamente, dentro ou fora do espaço religioso. Percebeu-se que é necessário compreender essa Informação Religiosa para melhor entender as problemáticas da área e as dinâmicas da comunicação na sociedade.

Dessa forma, os objetivos do trabalho foram de analisar como a informação é mediada no discurso de Edir Macedo por meio de editoriais do 
jornal Folha Universal utilizando-se da Análise do Discurso (AD) como metodologia. Além disso, verificar quais os mecanismos de linguagem utilizados pelo bispo e transcrever os principais termos e conceitos que dão respaldo a sua argumentação.

Procuramos por meio da $A D$, da $\mathrm{Cl}$ e da informação veiculada nos editoriais escritos por Edir Macedo, compreender os enunciados, as estratégias discursivas e principalmente quais as intenções do sujeito falante e os vários discursos presentes nessas formações, como bem observa Foucault:

[...] não se pode reconstituir um sistema de pensamento a partir de um conjunto definido de discursos. Mas esse conjunto é tratado de tal maneira que se tenta encontrar, além dos próprios enunciados, a intenção do sujeito falante, sua atividade consciente, o que ele quis dizer, ou ainda o jogo inconsciente que emergiu involuntariamente do que disse ou da quase imperceptível fratura de suas palavras manifestas; de qualquer forma, trata-se de reconstituir outro discurso, de descobrir a palavra muda, murmurante, inesgotável, que anima do interior a voz que escutamos, de restabelecer o texto miúdo e invisível que percorre o interstício das linhas escritas e, às vezes, as desarruma (FOUCAULT, 2009, p. 31).

O sujeito falante (discursivo) deve ser compreendido em suas "posições discursivas" em que as palavras são produzidas. Edir Macedo possui posição discursiva privilegiada, ou seja, ocupa seu lugar de representação em um determinado grupo, e a significação de suas palavras deve ser entendida de acordo com suas posições ideológicas.

Vale lembrar que conjuntamente com o sujeito falante e as posições ideológicas presentes nos enunciados dos editoriais da Folha Universal encontra-se a necessidade de compreender o discurso religioso e seus mecanismos de comunicação. No discurso religioso, o sujeito discursivo fala em nome de Deus, como bem relata Eni Orlandi ao afirmar que o discurso religioso realiza tarefa sui generis enquanto mecanismo de comunicação, pois, se os demais discursos podem vir a revelar a voz do sujeito falante, nele resta apenas a noção de dogma: "Deus não fala, dada ser uma realidade imaterial; quem fala em seu nome não é dono do discurso: o agente é apenas veículo, porta-voz, no máximo interpretador palavra do Senhor" (ORLANDI, 2003, p.61). 
O discurso religioso tem como base de organização a persuasão, ou seja, se utiliza de mecanismos de persuasão para atingir seus objetivos. Segundo Citelli (2007) esses mecanismos são: o uso do modo imperativo, o que revela a ideia de coisa pronta, acabada; o vocativo subjacente (creio), que afirma o chamamento ao sujeito; a função emotiva (afinal eu devo acreditar, ter fé. O problema da salvação está comigo, o Senhor é o exemplo a ser seguido) o uso de metáforas que acentuam o ciframento do discurso religioso: a mansão dos mortos e o ressuscitamento de todos só criam um jogo simbólico acerca do inusitado do dogma; o uso intenso de parábolas e da paráfrase; de um lado, a evocação alegórica, e, de outro, a presença do texto bíblico; uso de estereótipos, chavões e de sintagmas cristalizados: Oh! Senhor, todopoderoso, criador, nosso Senhor, etc.

Vale destacar que não entendemos o usuário (leitor) da Folha Universal como mero receptor do discurso de Edir Macedo, mas como alguém que interage com esse suporte (contato) sendo que essa informação só passa a existir no processo de apropriação, ou seja, no momento da mediação:

A mediação da informação permite e exige concepção de informação que desloque o usuário da categoria de mero receptor, colocando-o como ator central do processo de apropriação. Dessa forma, defendemos que o usuário é quem determina a existência ou não da informação. A informação existe apenas no intervalo entre o contato da pessoa com o suporte e a apropriação da informação. Como premissa, entendemos a informação a partir da modificação, da mudança, da reorganização, da reestruturação, enfim, da transformação do conhecimento. Assim entendida, ela, informação, não existe antecipadamente, mas apenas na relação da pessoa com o conteúdo presente nos suportes informacionais. Estes são concretos, mas não podem prescindir dos referenciais, do acervo de experiências e do conhecimento de cada pessoa. Em última instância, quem determina a existência da informação é o usuário, aquele que faz uso dos conteúdos dos suportes informacionais. (ALMEIDA JÚNIOR, 2009, p. 97).

Nesse sentido, a informação é entendida como relevante no momento de sua apropriação, ou seja, na medida em que interage com o usuário e promove mudanças. Pinheiro e Loureiro ao analisar a informação, destacam a distinção feita por Saracevic acerca da informação e da informação relevante 
segundo a qual esta última está relacionada à comunicação e a orientação aos usuários de sistemas de recuperação da informação. Assim sendo, a [...] efetividade da comunicação do conhecimento se dá [...] na medida de sua transmissão de um arquivo ao outro, ocasionando mudanças (PINHEIRO; LOUREIRO, 1995). Portanto, relevância é a medida de tais mudanças, e a Ciência da Informação, ao lado da Lógica e da Filosofia, apresenta-se como disciplina essencial no território dos estudos e reflexões sobre relevância e, consequentemente, informação.

Assim sendo, essa mediação pode ser feita de várias maneiras de acordo com a posição discursiva e os interesses do sujeito falante, pois este a partir do local em que se encontra pode empreender adaptações (trocar as palavras) ao discurso religioso fazendo com que obtenha maior adesão do público:

Mas, se não há diferença importante entre uma e outra palavra, por que trocá-las? Que jogo retórico está por trás do eufemismo? A resposta nos remete a uma das vertentes do discurso persuasivo que é a de provocar reações emocionais no receptor: o enunciador/emissor apela para recursos afetivos visando melhor conquistar adesão do seu público (CITELLI, 2007, p. 61).

Tanto a AD como a $\mathrm{Cl}$ estudam o comportamento da informação em seu processo de comunicação, ambas as áreas de pesquisa dependem do ato da mediação da informação para que possam existir, ou seja, tanto na linguagem, como na seleção, organização e uso, há interferência e apropriação da informação. Assim sendo, a necessidade de estudarmos a mediação da informação feita pelos editoriais da Folha Universal dentro da $\mathrm{Cl}$ pareceu evidente, pois além de ser este (Edir Macedo) uma das principais vozes do Brasil, temos que saber lidar com esse tipo de informação. Por isso esse estudo sistemático com a utilização da $\mathrm{AD}$ tende a fazer contribuições essenciais para o desenvolvimento da $\mathrm{Cl}$. 


\section{RELIGIÃO, EDIR MACEDO E A IGREJA UNIVERSAL DO REINO DE DEUS (IURD) COMO ESPAÇO INFORMACIONAL}

Antes de começarmos a discorrer acerca da trajetória do bispo Edir Macedo para a constituição de um dos maiores espaços informacionais do país, é essencial apresentar qual a ideia de religião que utilizamos como ferramenta de abordagem para o desenvolvimento do texto. Peter Berger de acordo com a concepção luckmanniana relata que a:

[...] religião é a capacidade de o organismo humano transcender sua natureza biológica através da construção de universos de significado objetivos, que obrigam moralmente e que tudo abarcam. Consequentemente, a religião torna-se não apenas o fenômeno social (como em Durkheim), mas na verdade, o fenômeno antropológico por excelência. Especificamente, a religião é equiparada com autotranscedência simbólica. Assim, qualquer coisa genuinamente humana é ipso facto religiosa e os únicos fenômenos não-religiosos na esfera humana são os baseados na natureza animal do homem, ou mais precisamente, aquela parte de sua constituição biológica que ele tem em comum com os outros animais (BERGER, 1985, p.118).

Nesse sentido, a Informação Religiosa é um produto da atividade humana e é essa atividade que nos propusemos a entender. A partir dessa lógica de querer entender a sociedade e suas problemáticas como a religião, a Informação Religiosa e principalmente a IURD, é que elas se destacam como importante filão de pesquisa dentro da $\mathrm{Cl}$. A história da fundação da Igreja Universal do Reino de Deus (IURD), o seu crescimento exacerbado, a expansão na mídia e o poder de influência social têm conquistado grande interesse dos pesquisadores de múltiplas áreas do conhecimento.

A IURD foi fundada em 1977 e teve, desde os seus primórdios, Edir Macedo como uma das mais expressivas e carismáticas lideranças. O poder e a eloquência do discurso mediado pelo bispo Edir Macedo sobre os fiéis, encontra-se em posição de destaque frente às transformações da sociedade contemporânea. Esse impressionante discurso mediado pelo bispo, talvez seja uma das principais formas de compreendermos os motivos pelos quais a IURD conquistou tanto espaço no cenário nacional e internacional, sendo esta uma 
das principais instituições religiosas que medeia informação para um número cada vez mais crescente de evangélicos. Para Zilles, "[...] não se pode entender o fenômeno da Igreja sem o talento de Macedo" (ZILLES,1998, p. 34).

Desde a década de 1990 até os dias atuais, muitas denúncias têm envolvido a Igreja Universal, dentre elas: formação de quadrilha, lavagem de dinheiro sob denúncia do Ministério Público de São Paulo, que acusa Edir Macedo e demais envolvidos, de se utilizarem por 10 anos da Igreja Universal para a prática de fraudes em detrimento da própria igreja e de inúmeros fiéis. Foram acusados também de movimentação suspeita que teria somado $R \$ 4$ bilhões de 2003 a 2008, sendo estes recursos destinados à compra de emissoras de TV e rádio, financeiras, agência de turismo, jatinhos, entre outros. Como foi destacado inicialmente, não estamos preocupados em angariar culpados para tais fatos, nem em negar a importância de tais descobertas e a necessidade de serem tomadas as devidas punições, mas de compreender como é construído esse discurso (Informação Religiosa) responsável por promover tais impactos sociais.

\subsection{Igreja: um elemento na concepção de espaço informacional}

A ideia de ambiente ou espaço informacional dentro da $\mathrm{Cl}$ está quase sempre ligada a bibliotecas, arquivos, museus, empresas, organizações, etc. Sem negar a importância dessa concepção, já que é fundamental pensar o fluxo informacional nesses ambientes, decidimos propor a ampliação da concepção de espaço informacional. Nesse sentido, o espaço sagrado aparece como importante unidade informacional. Este espaço sempre existiu ao longo da história, desde os primórdios das civilizações, o homem reservava alguns espaços para as divindades, como por exemplo, o culto ao fogo, o culto aos mortos e posteriormente a construção de pirâmides. Ao longo dos anos outros espaços sagrados surgiram como igrejas, sinagogas, mesquitas, templos, terreiros, centros, entre outros.

Vale ressaltar que a concepção de espaço para o homem religioso não é a mesma que para o homem profano. Para o primeiro, o espaço sagrado não é homogêneo: 
Para o homem religioso, o espaço não é homogêneo: o espaço apresenta rupturas, quebras, há porções de espaço qualitativamente diferente das outras, "não te aproximes daqui, disse o Senhor a Moisés, tira as suas sandálias de teus pés, porque o lugar onde te encontras é uma terra santa" (Êxodo, 3:5) [...] Mais ainda: para o homem religioso essa não homogeneidade espacial traduz-se pela experiência de uma oposição entre o espaço sagrado - o único que é real, que existe realmente - e todo o resto, a extensão informe, que o cerca (ELIADE, 1992, p. 25).

Dessa forma, o homem religioso cria o seu próprio espaço, sendo este, para ele, o único que é real. Assim, esse espaço não homogêneo que é sagrado se opõe ao espaço profano, ou melhor, a todos os espaços que não sejam os que criam a sua realidade. Nesse sentido, quase tudo o que acontece nesse espaço, como por exemplo, cultos, leituras e interpretações da bíblia e da sociedade, valores de consumo, posturas diante da vida, posicionamentos políticos, doações, afetividades, etc., são vistas como mais reais do que as que acorrem em outros espaços.

Fato que demonstra a força do discurso da IURD e de Edir Macedo para a formação da opinião dos fiéis. A igreja sustenta rotina assídua de cultos, como observou Mariano: "[...] a Universal abre seus templos religiosamente todos os dias para a realização de três a quatro cultos públicos" (MARIANO, 2004, p. 6).

Além disso, mantém forte influência na imprensa, tanto com canais de televisão e rádio funcionando $24 \mathrm{hs}$, como divulgando sua doutrina por meio de jornais e revistas. Essa postura faz com que a igreja consiga ampliar seu espaço informacional para um número cada vez maior de pessoas. Talvez essa seja uma das explicações para o crescimento exacerbado da IURD, que em três décadas se tornou um dos mais importantes espaços religiosos do país.

Atualmente a IURD existe em quase todas as cidades brasileiras, onde quer que exista possibilidade de crescimento, adeptos e fiéis-leitores a igreja é construída. Em julho de 2014 inaugurou o famoso Templo de Salomão, complexo que tem capacidade para 10 mil pessoas sentadas, estacionamento para mais de mil carros, escola bíblica para mais de 1.300 crianças, auditório para 500 pessoas e estúdio de rádio e televisão. 
A IURD é responsável por alteração no espaço urbano de inúmeras cidades, como por exemplo, Uberlândia:

[...] partindo do princípio de formação de região e de controle de territórios, constatamos que a IURD instala-se em bairros com índices de pobreza mais elevados. Essa dinâmica de instalação em bairros mais pobres da cidade não é uma particularidade de Uberlândia, uma vez que isso é uma estratégia utilizada pela igreja. Constatamos também que essa igreja se utiliza de cultos para conseguir fiéis. Assim, acreditamos que a IURD está sendo responsável por alterações no modo de vida de seus fiéis, e que como conseqüência disso, está alterando a organização do espaço urbano de Uberlândia (SILVA et al., 2003, p. 9).

Essa dinâmica de instalação em bairros mais pobres da cidade continua vigente, no entanto, a igreja também avançou para os bairros ricos das cidades e centros. Além disso, a IURD vem conquistando um público cada vez mais abastado, como empresários e universitários. A importância da IURD como espaço informacional é explícito, tanto que o biógrafo de Edir Macedo e funcionário da Rede Record, Douglas Tavalaro, ao falar da expansão da igreja em outros países, fez comparações com empresas multinacionais como, por exemplo, Mc Donald's e Philips Morris:

O mapa da expansão não tem contornos. Ultrapassou as fronteiras do Brasil ainda nos anos 1980: América, Europa, Ásia e África. A presença da igreja já é maior que a de muitas multinacionais de porte - a Philips Morris, dona da marca de cigarros Malboro, por exemplo, está em 160 países e o Mc Donald's, famosa rede de fast food, em 118. A Universal já chegou em 180 países. A cada quinze dias, um pastor se transfere para fora do país. Prega-se em inglês, espanhol, russo, japonês, africâner, zulu, entre outros idiomas, sem contar os dialetos. A maioria dos religiosos viaja sem conhecer a língua estrangeira (TAVALARO, 2007, p. 245).

Dessa forma, a IURD se destaca também como um importante espaço informacional internacional, que tem como pressuposto romper fronteiras e levar sua mensagem ao mundo. Isso torna o discurso da IURD e principalmente de Edir Macedo mais intrigante, pois ele não se limita a interagir com apenas a sociedade brasileira, mas tem aprovação por grande parte da população mundial. 
A igreja se utiliza de muitas propostas para solucionar problemas, como por exemplo: vícios, desemprego, nervosismo, depressão, problemas familiares, filhos rebeldes, enfermidades crônicas, espíritos obsessores, desejo de suicídio, insônia, olho grande, entre outros. Faz correntes da prosperidade, descarrego, família, libertação, causas impossíveis, etc., de segunda a sextafeira. Esse espaço informacional todo dia interage com os fiéis - leitores oferecendo proteção contra os males do mundo, o que o torna um espaço sagrado que serve de escudo para o homem contra o terror do caos, como bem observa Berger:

O cosmos sagrado, que transcende e inclui o homem na sua ordenação da realidade, fornece o supremo escudo do homem contra o terror da anomia. Achar-se numa relação "correta" com o cosmos sagrado é ser protegido contra o pesadelo das ameaças do caos. Sair dessa relação "correta" é ser abandonado à beira do abismo da incongruência. Não é fora de propósito observar aqui que o vocábulo "caos" deriva de uma palavra grega que quer dizer "voragem" e que "religião" vem de uma palavra latina que significa "ter cuidado". Por certo, aquilo sobre o que o homem anda "cuidadoso" é sobretudo 0 poderoso poder inerente às próprias manifestações do sagrado. Mas por trás desse perigo está o outro, muito mais horrível, de que se possa perder toda conexão com o sagrado e ser engolido pelo caos (BERGER, 1985, p. 40).

A ideia de anomia, em português, utilizada por Peter Berger é uma adaptação do anomie de Durkheim que se refere à ruptura das normas de comportamento postuladas pela sociedade. Na concepção Durkheiminiana os homens são forçados a impor uma ordem significativa à realidade e essa ordem pressupõe o empreendimento social de ordenar o mundo. Nesse sentido, a anomia é vista como uma possibilidade de romper a ordem do mundo (profano) criando outra forma de ordenação, o nomos do espaço sagrado. Dessa forma, o espaço sagrado passa a existir como realidade. Sendo assim, o espaço informacional no ambiente sagrado é único, existe como realidade e serve de proteção contra o caos do mundo profano.

O indivíduo ao adentrar a IURD, ou seja, a um espaço religioso encontra-se em uma estrutura de plausibilidade que the proporciona conforto e 
sensação de bem-estar, pois ele está rodeado de indivíduos que compartilham do seu nomos, como relata Berger:

Para o indivíduo, existir num determinado mundo religioso significa existir no contexto social particular no seio do qual aquele mundo pode manter a sua plausibilidade. Onde o nomos da vida individual é mais ou menos coextensivo àquele mundo religioso, separar-se deste último implica em ameaça de anomia (BERGER, 1985, p. 41).

Dessa forma, o indivíduo torna o espaço religioso um espaço informacional único e totalmente real. Espaço em que pode manter a sua estrutura de plausibilidade. O que torna o problema da informação um fenômeno amplo e complexo, de forma que uma ciência que se limita a pesquisar apenas alguns espaços informacionais tende a não dar conta de compreender o seu próprio objeto. Isso é possível perceber, por exemplo, quando analisamos as estatísticas de leitura no Brasil.

Pesquisa publicada pelo Instituto Pro-Livro em 2015 divulgou que 66\% dos brasileiros não frequentavam bibliotecas, que o gênero mais lido pelos brasileiros é a Bíblia, além de ser citada como o livro mais marcante (INSTITUTO Pro-Livro, 2015). Assim sendo, é possível perceber que as bibliotecas - espaço informacional que é um dos principais objetos de pesquisas da $\mathrm{Cl}$ - são frequentadas por um público restrito, sendo as pesquisas desenvolvidas nesses espaços apenas uma das várias formas de contribuição para compreendermos os problemas informacionais. Observou-se também que a Informação Religiosa é uma das informações mais apropriadas pelos brasileiros.

Dessa forma, a igreja é um espaço informacional essencial para tentarmos compreender os problemas informacionais, pois além de mediar informação para um número amplo de pessoas, ainda é capaz de criar um espaço único e fundamental na produção do conhecimento. Portanto, conjuntamente com a ideia de espaço informacional como bibliotecas, arquivos, museus e organizações são possíveis pensar a igreja também como um importante espaço informacional responsável por formar opiniões, direcionar 
Ciro Athayde Barros Monteiro, Oswaldo Francisco de Almeida Junior

A informação mediada no discurso de Edir Macedo: análise de editoriais da Folha Universal

condutas de vida e principalmente existir como ordenação do mundo e da realidade.

\subsection{Edir Macedo: mediador da informação}

Uma das principais características do bispo Edir Macedo é o seu impressionante discurso, o impacto que este causa nas pessoas e o poder de conquistar novos fiéis-leitores. Segundo Douglas Tavalaro, Edir Macedo começou a discursar aos sábados, no jardim do Meier, subúrbio carioca. Usava apenas um teclado, um microfone, uma caixa de som e uma Bíblia (TAVALARO, 2007). Discursava sobre um telhado e aos poucos foi juntando pequenos grupos de pessoas. Hoje, dono de um dos maiores impérios de comunicação do Brasil, seu poder de influência é muito grande. Os pastores da IURD têm o bispo como espelho. Fato que justifica a escolha de Edir Macedo (seu discurso) como objeto de pesquisa, já que o consideramos um dos principais mediadores sociais da atualidade.

O líder da IURD insere-se no rol de intelectuais responsáveis por criar ideias e organizar o real. De acordo com Solange Mustafá os pastores são um dos grupos funcionalizados por uma instituição, também responsáveis por moldar nosso comportamento, visão e sobrepor uma hegemonia para o saber:

Na sua historicidade e inteireza, o saber é orgânico, no sentido de ser organizador do real. $O$ saber passa a desorganizar o real para organizar a hegemonia da classe dominante. É nesse sentido que muitas teorias, muitos paradigmas, muitas filosofias e ciências são degradadoras do real. A desagregação é concreta. Está posta através de intelectuais, sejam cientistas, pastores, professores e bibliotecários. Intelectuais que estão funcionalizados nas instituições como a imprensa, a escola, a igreja ou a biblioteca. Esses intelectuais são os criadores e difusores de teorias e idéias que chegam até o nosso cotidiano, moldando a nossa visão, atitude, hábito, motivação, comportamento ou opinião (MOSTAFA; LIMA; MARANGON, 1992, p. 221).

Dessa maneira, entendemos Edir Macedo como um intelectual, pois cumpre uma função organizadora na sociedade e foi elaborado por uma classe ou grupo em um determinado momento histórico. Essa visão não caracteriza o bispo como sendo um intelectual orgânico no sentido de que seja capaz de 
Ciro Athayde Barros Monteiro, Oswaldo Francisco de Almeida Junior

A informação mediada no discurso de Edir Macedo: análise de editoriais da Folha Universal

romper com os intelectuais tradicionais e promover transformações sociais vinculadas a uma sociedade planificada, mas permite que possamos pensar os mediadores sociais e a informação como não neutra, carregada de ideologias e interesses.

Maria Helena Toledo Costa de Barros, em pesquisa sobre a leitura no período escolar, aponta para a importância da parcialidade dos mediadores da informação, dentre eles do professor e do bibliotecário:

Entre a infância e a adolescência, no período da escolaridade, os mediadores mais citados nas pesquisas são o professor e o bibliotecário, este de forma mais tímida do que o primeiro; mesmo porque não se pode afirmar que existe necessariamente um bibliotecário adequado em cada uma das escolas, nem que cada escola tenha sua biblioteca (BARROS, 2006, p. 138).

Assim como o pastor, o professor e o bibliotecário são mediadores da informação vitais para o processo de organização do real e formação da sociedade. Entender esses mediadores como intelectuais é dar margem para esboçar uma nova visão acerca da informação mediada nos múltiplos espaços informacionais. A insistência da $\mathrm{Cl}$ em conceber apenas a informação registrada como objeto de pesquisa faz com que ela acabe por trabalhar com um público seleto, muitas vezes proveniente de determinados grupos sociais privilegiados. A biblioteca, por exemplo, é um desses grupos privilegiados, que segundo Almeida Junior, direciona suas ações para o público que a procura, ou seja, àqueles que já têm acesso à informação:

O bibliotecário, dentro dessa concepção, passa a ser um profissional voltado para um pequeno e seleto segmento social, embora hegemônico quanto aos instrumentos ideológicos de exclusão social que domina. Os espaços onde atua são concebidos e estruturados para atender a uma demanda oriunda daqueles que já têm acesso à informação (ALMEIDA JÚNIOR, 2004b, p. 79).

Se compararmos bibliotecários e pastores ambos são mediadores sociais e têm uma função orgânica na sociedade, no entanto trabalham com públicos diferentes. Os primeiros, como observado acima, acabam sendo direcionados por um público alfabetizado. Isso é possível observar quando 
adentramos a uma biblioteca universitária em campus como a Universidade de São Paulo (USP). Um cidadão que não faça parte do rol de universitários provavelmente terá grandes dificuldades de acessar a informação desejada. Os pastores trabalham com um público múltiplo, dentre eles, universitários, alcoólatras, moradores de rua, presidiários, entre outros. Independentemente de público alvo ou objeto, a questão que "salta aos olhos" é a de que quando nos preocupamos com a circulação da informação na sociedade passamos a dar importância aos mais variados mediadores sociais e problemáticas informacionais sendo essas algumas das preocupações da $\mathrm{Cl}$.

Para Jean Davallon a noção de mediação aparece sempre que há necessidade de descrever uma ação implicando uma transformação da ação ou do dispositivo comunicacional, e não uma simples interação entre elementos já constituídos (DAVALLON, 2007). Assim sendo, a mediação opera a relação entre uma manifestação, um indivíduo e o mundo de referência. Dessa maneira, compreendemos que os editoriais da FU é um importante dispositivo que medeia fatos da realidade para um público amplo e é responsável por uma ação de transformação da sociedade. Nesse sentido, portanto, Edir Macedo é um mediador social e produtor de um grande fluxo de informações para um público múltiplo. Isso torna o discurso do bispo um objeto essencial de pesquisa, responsável por formar opiniões, posturas de vida, direcionar e construir o mundo e a realidade.

\section{CONSTITUIÇÃO DO CORPUS E OBJETO DE ANÁLISE}

Selecionamos 4 editoriais da Folha Universal publicados entre os anos de 2009 e 2011, sendo eles presentes nos seguintes números: 919 Estrelas Quebradas (Editorial: A oferta nos torna merecedores), 937 Chegou o grande dia D (Editorial: Como receber o Espírito Santo), 943 Brasil de fé (Editorial: Mar de Conquistas) e a Edição Histórica que saiu no dia 21 de abril de 2011 (Editorial: Como esta data pode definir a sua vida).

Esses editoriais são assinados por Edir Macedo e publicados, principalmente, na página 3i. Foram selecionados de acordo com a 
repercussão que a temática causou na imprensa, ou por trazer relatos interessantes que sintetizam a visão do líder e dos membros da IURD. É importante salientar que em algumas edições, como por exemplo, de número 943 o editorial foi substituído por reportagens que exaltava a figura de Edir Macedo.

A edição número 937 Chegou o grande dia $D$, marca o período em que a IURD se une para responder a acusações de corrupção feitas pela imprensa a Igreja. Dessa forma, as edições selecionadas não foram aleatórias, pois retratam períodos ou momentos essenciais em que a IURD ou o bispo Edir Macedo tiveram que se posicionar mediante os acontecimentos e repercussões da sua igreja na mídia. A partir desse corpus e com auxílio de livros do líder como, por exemplo, Somos todos filhos de Deus?, de sua biografia O Bispo escrita pelo jornalista Douglas Tavalaro, e principalmente do aparato teórico da $\mathrm{Cl}$ e da $\mathrm{AD}$, empreendemos análise do discurso mediado por Edir Macedo por meio dos editoriais.

\subsection{A Análise do Discurso de linha francesa}

Ao pesquisar o significado de um discurso frequentemente fazemos distinção dos seus diferentes tipos como se fosse possível analisá-los separadamente. Assim sendo, ao fazermos a separação entre tipos de discurso (político, filosófico, religioso), limitamos esses a um determinado espaço e deixamos de perceber que tanto os filósofos como o político e o homem religioso fazem uso dos mais variados tipos de discursos de acordo com o espaço e a posição discursiva que esteja ocupando.

Dessa forma, surge como necessário analisar o uso da linguagem e não apenas o seu tipo, como bem observa Conesa e Nubiola:

Es frecuente clasificar los tipos de discurso atendiendo a su contenido. Así se habla de discurso político, discurso filosófico, discurso científico o discurso religioso. [...] Este tipo de clasificaciones tiene, sin embargo, el inconveniente de que tiende a aislar los diversos tipos de discurso si fueran realidades autónomas que no se relacionan entre si. Si así fuera, no sería posible la comunicación entre un político y un filósofo o entre un científico y un hombre religioso. El discurso que usa el político, por ejemplo, aun cuando sea peculiar, suele 
resultar compreensible para todos los que le escuchan. Poe ello, más que de lenguaje político o de lenguaje filosófico, convendría hablar de uso político o uso filosófico da lenguaje. Lo mismo debe decirse del lenguaje religioso (CONESA; NUBIOLA, 2002, p. 264).

Nesse sentido, para perceber o uso da linguagem religiosa a $A D$ é uma importante ferramenta para compreensão do sujeito discursivo e suas várias estratégias discursivas utilizadas em cada espaço informacional. Segundo Maria do Rosário Gregolin, AD francesa surgiu do efeito do encontro entre psicanálise, marxismo e linguística antropológica, em um período de reestruturação global de afinidades disciplinares:

A análise do discurso francesa surgiu nesse contexto (hegemonia teórica da Gramática Gerativo Transformacional e a releitura de Marx, Freud e Saussure, operada por LéviStrauss, Lacan, Althusser, Foucault e Derrida). A releitura de Saussure foi um dos principais motores desse movimento, cujo princípio era separar a linguística do funcionalismo sóciopsicologista, apoiando-se principalmente, nos trabalhos de Jakobson e de Benveniste. A análise do discurso francesa surgiu nesse contexto, como disciplina transversal fortemente marcada por essa conjuntura epistemológica. Ocorreu nesse período que vai de 1960 a 1975, uma reestruturação global da rede de afinidades disciplinares em torno da Linguistica (GREGOLIN, 2004, p. 32).

Essa reestruturação foi o estruturalismo, que abriu espaço para a renovação da epistemologia e da história das ciências e novas formas de escrita literária. Com a contribuição de várias áreas do conhecimento, a $A D$ surgiu como uma disciplina interdisciplinar. Para a $A D$ não existe sentido discursivo sem sujeito e ideologia:

O sentido é assim uma relação determinada do sujeito afetado pela língua - com a história. É o gesto de interpretação que realiza essa relação do sujeito com a língua, com a história, com os sentidos. Esta é a marca da subjetivação e, ao mesmo tempo, o traço da relação da língua com a exterioridade: não há discurso sem sujeito. $E$ não há sujeito sem ideologia. Ideologia e inconsciente estão materialmente ligados (ORLANDI, 2003, p. 47).

Dessa forma, a AD contribui para que possamos melhor compreender as vozes dos sujeitos discursivos, os lugares de enunciação, e como o discurso 
autoritário, persuasivo e principalmente o religioso, objeto de nossa análise, interage com as pessoas. A contribuição de Foucault também é muito importante para a $A D$. Existem muitos debates que não aceitam Foucault como um teórico da $A D$, o que é justificável já que o autor nunca pretendeu escrever algo direcionado para tal disciplina. No entanto, sua contribuição é inegável, como por exemplo, o conceito de formação discursiva.

Em seu livro Arqueologia do saber, ao refletir acerca do campo dos acontecimentos discursivos, elenca a seguinte questão: "[...] como apareceu um determinado enunciado e não outro em seu lugar?" (FOUCAULT, 2009, p. 30). Essa questão é essencial, pois ao analisarmos uma formação discursiva devemos nos ater a questões sobre o porquê que não poderia ser outro discurso, como este exclui o outro, de que maneira ele ocupa um lugar que nenhum outro poderia ocupar.

Essas problemáticas dizem respeito principalmente ao cruzamento de relações de poder e relações de saber. Essas estão quase sempre vinculadas à ideia de dispositivo de Foucault, sistematizada por Agamben: "[...] qualquer coisa que tenha de algum modo a capacidade de capturar, orientar, determinar, interceptar, modelar, controlar e assegurar os gestos, as condutas, as opiniões e os discursos dos seres viventes" (AGAMBEN, 2009, p. 40).

Nesse sentido, a ideia de Foucault de formação discursiva e de dispositivo contribuiu para nossa pesquisa, pois passamos a compreender que a Igreja Universal do Reino de Deus e seu jornal são dispositivos que exercem grande influência e poder na formação dos discursos da sociedade. De modo geral, a $A D$ de linha francesa é uma ferramenta essencial para analisarmos a construção discursiva de um determinado grupo, instituição, etc., como por exemplo, a IURD e o seu líder.

\section{DISCURSO DE EDIR MACEDO NOS EDITORIAIS DA FOLHA UNIVERSAL}

\subsection{Editorial: A oferta nos torna merecedores}

O editorial "A oferta nos torna merecedores" abordou a temática da importância do "dízimo" para os fiéis e membros da igreja, tema recorrente nos 
editoriais da Folha Universal. O editorial vai ao encontro do destaque da capa do jornal, que trouxe a questão do mau uso do dinheiro feita pelas celebridades o que traz como consequência a ruína financeira. Na concepção do bispo Macedo, os males são causados porque a oferta a Deus é mal feita.

O líder da IURD utiliza-se de citações bíblicas para dar respaldo a sua argumentação. Segundo o bispo:

Pela fé, Abel ofereceu a Deus mais excelente sacrifício do que Caim; pelo qual obteve testemunho de ser justo, tendo a aprovação de Deus quanto às suas ofertas. Por meio dela, também mesmo depois de morto, ainda fala (Hebreus 11.4). Abel foi justificado por Deus por causa de sua oferta de fé. Por isso, ele se tornou merecedor diante do Senhor. Assim também acontece conosco. Quando apresentamos uma oferta diante de Deus, nos tornamos merecedores. Porém, não é qualquer oferta. Tanto a de Abel quanto a do Senhor Jesus foram de sacrifício (MACEDO, 2009, p. 3i).

Percebe-se que a citação bíblica, ou seja, o exemplo de que Abel foi mais justo do que Caim em sua oferta e recebeu aprovação de Deus foi logo em seguida comparado as ações dos homens ou dos fiéis, que para ofertar tem que ser justo diante de Deus. Para se tornar merecedor é necessária uma oferta de sacrifício. Esse discurso tem uma das principais características de um discurso persuasivo, o uso intenso de citações bíblicas que sevem para afirmar, por meio da voz de Deus, o que o sujeito fala. Segundo Jorge Luis Torresan existe justificativa para o excessivo uso de citações bíblicas feitas pelos evangélicos, cuja genealogia encontra-se na Reforma Protestante. Uma das principais reivindicações dos reformadores era a livre leitura da bíblia, que contrariava os preceitos católicos. Dessa maneira, "[...] o uso constante de passagens bíblicas reflete a tentativa de provar, a todo instante, o resgate e 0 seguimento da verdadeira palavra de Deus" (TORRESAN, 2004, p. 94).

O editorial apresenta a derrota e a ausência de sucesso dos pastores, obreiros ou funcionários da IURD como consequência da precária oferta feita a Deus:

Às vezes o pastor não cresce em seu ministério porque a sua oferta não agrada a Deus. Da mesma forma acontece com o obreiro ou até mesmo com o funcionário da IURD que não tem tido sucesso devido ao que vem oferecendo ao Senhor. A sua 
vida é resultado da oferta que você coloca no altar (MACEDO, 2009, p. 3i).

A frase "A sua vida é resultado da oferta que você coloca no altar" demonstra a extrema importância que o discurso de Edir Macedo dá as ofertas. Essa concepção de oferta e consumo para obter a felicidade terrena é uma das características da IURD, já que seus fiéis devem ter acesso a bens de consumo. Para o bispo: "Aquilo que apresentamos a Deus mostra o que somos diante dele, ou seja, se realmente somos sinceros ou se somos hipócritas".

Portanto, devemos ter a consciência disso: "a nossa vida depende do que ofertamos a Deus" (MACEDO, 2009, p. 3i). Nesse sentido, o discurso de Edir Macedo no editorial "A oferta nos torna merecedores" revelou a necessidade de ofertar a Deus para obter sucesso e prosperidade, já que a precariedade dessa oferta pode gerar derrotas e ruína financeira. A informação mediada pelo bispo deixa evidente que o principal culpado por todos os males é a própria ausência de fé e dedicação dos fiéis.

Dessa forma, é importante salientar que a informação mediada aqui tem as características de um discurso religioso e persuasivo, quando o enunciador fala como representante de Deus, argumentando que a culpa de todos os males é a precária oferta feita a Deus.

\subsection{Editorial: Como receber o Espírito Santo}

O editorial "Como receber o Espírito Santo" é um manual escrito pelo líder da IURD de como se preparar para a chegada do espírito santo. Este número da Folha Universal ( $n^{\circ}$ 937) trouxe como capa o vice-presidente do Brasil na época, José de Alencar, que foi apresentado como um exemplo de superação e perseverança. Essa capa está totalmente conectada com o editorial, já que o texto apresenta os passos a serem seguidos com muita persistência para alcançar o espírito santo. O vice-presidente José de Alencar após 12 anos e mais de 15 cirurgias controlou o câncer e conseguiu manter-se na vida política e profissional. Vale lembrar que o ex-presidente era pertencente ao Partido Republicano (PR), partido que juntamente com o Partido dos Trabalhadores (PT) foi apoiado por Edir Macedo e pela IURD nas 
Ciro Athayde Barros Monteiro, Oswaldo Francisco de Almeida Junior

A informação mediada no discurso de Edir Macedo: análise de editoriais da Folha Universal

eleições e que após a vitória do PT nas eleições, obteve cargos políticos em várias cidades.

O editorial apresenta três passos a serem seguidos para alcançar o espírito santo, sendo eles a consciência, o querer e o pensamento. Segundo o bispo o primeiro passo é a Consciência:

Estar consciente de que ninguém é batizado com o Espírito Santo porque merece. Se achar que tem méritos, não vai receber nunca. Esse batismo deve ser buscado com todas as forças e de todo o coração, por meio da fé do Senhor Jesus Cristo (MACEDO, 2010, p. 3i).

O segundo passo é o querer:

Esse querer não é simples vontade ou boa idéia, nem porque outros $\mathrm{O}$ têm. Mas, por ser tão necessário quanto à salvação. É um querer semelhante ao perdão dos pecados. É um querer ardente, acima de qualquer outro sonho ou desejo de coração. Mais do que viver, casar, conquistar mundos e fundos, enfim, mais do que tudo o que as pessoas ou esse mundo podem oferecer. Por isso, o Senhor impõe a condição de sede. É preciso ter sede. Desesperadora sede. Se alguém tem sede...(João 7.37) Se não houver garra no querer fica difícil (MACEDO, 2010, p. 3i).

E o terceiro passo é o pensamento:

O querer precisa ser seguido pelo pensamento ocupado na Pessoa do Espírito Santo. O pensamento contínuo nEle deve ser tanto em casa, no trabalho, na rua, na igreja ou em qualquer lugar. Tanto quanto puder. É como o namoro. Quando se está amando, a pessoa vira e mexe sempre está pensando na pessoa amada, não é? O mesmo deve ocorrer com o candidato ao Selo Divino. O importante é manter a mente focada nEle. Não é preciso dizer que nessa fase, o candidato deve procurar ao máximo se isolar de tudo que é nocivo à boa consciência. Evitar más companhias ou de pessoas contrárias a fé, distrações vulgares e tudo o mais que interrompa o relacionamento com o Espírito. É difícil, mas não é impossível. A fé exige sacrifícios, quanto mais na conquista espiritual. Imagine a plenitude do Espírito Santo! Portanto, tem de haver o esforço sobrenatural (MACEDO, 2010, p. 3i).

O discurso do editorial, por meio de um tripé "consciência, querer e pensamento" apresentou um manual para que os fiéis possam alcançar o batismo e receber o espírito santo. Percebe-se que o enunciado prioriza a 
questão da fé, ou seja, é só através dela que é possível receber o espírito santo. O bispo se utiliza de comparações, como exemplo, quando relata que o pensamento deve ser como o namoro, ou que é necessário ter sede para alcançar os objetivos.

Essas comparações ou trocas de palavras são vertentes do discurso persuasivo que tem por finalidade provocar a reações emocionais no receptor. As comparações ou troca de palavras conseguem maior adesão do público. É importante salientar que esses discursos são ideologicamente construídos seguindo uma ordem persuasiva e de conhecimento.

\subsection{Editorial: Como esta data pode definir a sua vida.}

A edição histórica da $F U$ do dia 21 de abril de 2010, intitulada Chegou o Grande Dia D, editou 1.306.000 exemplares e foi distribuída para grande parte dos fiéis, quando segundo a IURD, uniu mais de 8 milhões de pessoas nas 27 capitais de todo país. A foto da vista aérea do autódromo de Interlagos, em São Paulo, ilustra bem esse momento, em que se reuniram 2,3 milhões de pessoas para o evento.

Segundo o jornal, o encontro foi "[...] uma resposta à sequência covarde de ataques da mídia a IURD". A FU se referia as gravações publicadas pela Folha Online de um vídeo que foi entregue ao Ministério Público de São Paulo por um ex-voluntário da igreja que mostrou o bispo Romualdo Panceiro (braço direito de Edir Macedo) combinando a pregação para obter dízimos dos fiéis na crise econômica de 2008. Romualdo, apoiando-se em trechos da Bíblia, orientou que "semear" é dar dinheiro a igreja. O bispo Romualdo, segundo a Folha de S. Paulo, disse que a igreja deveria perguntar aos fiéis se eles "acreditam mais" na crise ou em Deus.

Para analisar esse editorial, podemos repetir a pergunta feita por Foucault (2007) sobre a descrição dos acontecimentos discursivos: "[...] como apareceu um determinado enunciado e não outro?”. Essa é uma pergunta que podemos fazer ao título da edição histórica chamada Dia $D$. Esse enunciado (Dia D) traz a ideia de um dos mais importantes acontecimentos da história na Segunda Guerra Mundial, quando no dia seis de junho de 1944, os aliados 
Ciro Athayde Barros Monteiro, Oswaldo Francisco de Almeida Junior

A informação mediada no discurso de Edir Macedo: análise de editoriais da Folha Universal

ocidentais desembarcaram nas costas da França, dando início ao fim da II Guerra Mundial, iniciada cinco anos antes pela invasão nazista à Polônia.

Simultaneamente ao desembarque do lado ocidental, no Leste da Europa, a URSS lançou uma poderosa ofensiva contra os nazistas. Onze meses depois a Alemanha nazista rendia-se para os vencedores. Em agosto de 1945, todas as ações militares haviam sido suspensas, encerrando a maior e pior guerra que a humanidade viveu, dando início à libertação europeia do domínio nazista.

A FU se utilizou deste enunciado para comparar o seu encontro a um marco histórico. No entanto, o enfoque foi outro, o editorial Como esta data pode definir a sua vida comparou o Dia da Decisão como sendo o momento em que os fiéis teriam a vida mudada por meio da fé e dos milagres divinos:

No grande evento, "O Dia D", que acontece hoje, todos os que crêem terão a vida mudada. Pois estes são os que vencem e experimentam os milagres de Deus. Como o senhor Jesus disse: "Esses sinais hão de acompanhar aqueles que crêem ..." (Marcos 16, 17), e você crê, também verá o sinal na sua vida (MACEDO, 2010, p. 8).

A estratégia de se utilizar de um evento histórico para dar notoriedade a um encontro de fé é uma característica do discurso persuasivo. Percebe-se que Edir Macedo utilizou-se, além da metáfora do acontecimento histórico, do modo imperativo "[...] todos os que crêem terão a vida mudada" para dar ênfase ao encontro como o verdadeiro dia da mudança de vida. Outra característica do discurso religioso, notável no trecho citado acima, é o uso de citações bíblicas, momento em que o dono do discurso (Edir Macedo) é o porta-voz da palavra do Senhor:

[...] o discurso religioso realiza tarefa sui generis enquanto mecanismo de comunicação, pois, se os demais discursos podem vir a revelar a voz do sujeito falante, nele resta apenas a noção de dogma. Não deixa de ser uma situação curiosa estar diante da mais visível forma de persuasão e do mais invisível eu persuasivo. Deus não fala, dado ser uma realidade imaterial; quem fala em seu nome não é dono do discurso: o agente é apenas veículo, porta-voz, no máximo "interpretador" da palavra do Senhor (ORLANDI, 1989, p. 61). 
Ciro Athayde Barros Monteiro, Oswaldo Francisco de Almeida Junior

A informação mediada no discurso de Edir Macedo: análise de editoriais da Folha Universal

O sujeito falante no discurso religioso é o agente mediador das palavras do Senhor e por isso tem impressionante influência social, já que é quem interpreta a palavra de Deus comunicando-a em um viés dogmático. O uso da função emotiva ficou explicito nos enunciados dos editoriais:

\begin{abstract}
Existe um determinado dia em que temos que fazer uma escolha definitiva para decidir nosso futuro. E essa é exatamente a proposta para "O Dia D". Eu me lembro que era recém-casado e tinha um sonho: o ideal de pregar o Evangelho. Mas, por força das circunstâncias, eu não conseguia realizar. Tinha que sair de casa pela manhã para trabalhar às $5 \mathrm{~h} 45$ e retornar as $23 \mathrm{~h} 30$, de segunda à sextafeira. Tinha dois empregos, dava aula particular e estudava na faculdade à noite. Não tinha tempo para mais nada. Houve um dia em que tive que tomar a decisão: uma porta se abriu e eu precisava passar por ela ou ignorá-la. Sacrifiquei o meu trabalho de 16 anos no Estado com todas as garantias e no qual havia alcançando um cargo de confiança que me proporcionava uma vida estável economicamente. Mesmo assim, pedi demissão. Foi como se uma pessoa tivesse se lançado de um prédio crendo que o Senhor fosse sustentá-la. Houve uma decisão pessoal, não pedi conselho a ninguém e me lancei de corpo, alma e espírito. E Deus tem mostrado, nestes mais de 30 anos de existência da igreja Universal, que ele é realmente o Deus de Abraão, Isaque e Israel (MACEDO, 2010, p. 8).
\end{abstract}

Uma das marcas do discurso de Edir Macedo no editorial é caracterizada pelo uso da função emotiva principalmente quando se trata de dar exemplos de vida, vitória e superação. Nesses momentos o autor se coloca como modelo de conquista, apelando quase sempre à função emotiva, sendo ele o modelo de homem objetivo "Eu me lembro que era recém-casado e tinha um sonho: o ideal de pregar o Evangelho", de homem trabalhador e estudioso: "Tinha que sair de casa pela manhã para trabalhar às $5 \mathrm{~h} 45$ e retornar as 23h30, de segunda à sexta-feira. Tinha dois empregos, dava aula particular e estudava na faculdade à noite", além de ousado e confiante: "Não tinha tempo para mais nada. Houve um dia em que tive que tomar a decisão: uma porta se abriu e eu precisava passar por ela ou ignorá-la. Sacrifiquei o meu trabalho de 16 anos no Estado com todas as garantias e no qual havia alcançando um cargo de confiança que me proporcionava uma vida estável economicamente. Mesmo assim, pedi demissão". No último trecho do editorial, em alusão ao Dia 
$D$, o bispo apresenta-se como um homem que tomou a decisão e foi auxiliado por Deus: "Foi como se uma pessoa tivesse se lançado de um prédio crendo que o Senhor fosse sustentá-la. Houve uma decisão pessoal, não pedi conselho a ninguém e me lancei de corpo, alma e espírito. $E$ Deus tem mostrado, nestes mais de 30 anos de existência da Igreja Universal, que ele é realmente o Deus de Abraão, Isaque e Israel".

Para finalizar a mensagem do editorial o bispo usa como metáfora a atitude de coragem aliado a fé em Deus para que os objetivos fossem alcançados, tomando como exemplo a sua própria atitude com Deus:

Nada caiu do céu. Tudo foi construído com as nossas próprias mãos, com muito trabalho, mediante a atitude que tomei com Deus. O Senhor quer fazer coisas grandes também na sua vida, mas depende da sua coragem. Você pode ter fé, mas se não uni-la à coragem de nada adianta. Abraão obedeceu e mostrou a Deus sua coragem. "O Dia D" será o dia da decisão para muitas pessoas! (MACEDO, 2010, p. 8).

Dessa maneira, é possível perceber que, no editorial Como esta data pode definir a sua vida, o discurso de Edir Macedo funcionou baseado principalmente pela função emotiva, sendo este responsável por criar a imagem do líder religioso como a de um homem objetivo, trabalhador, estudioso, ousado e confiante. De forma imperativa, apelando à função emotiva, e com o uso de metáforas e paráfrases que são características do discurso persuasivo, Edir Macedo exalta a sua imagem e tenta servir de modelo a ser seguido pelos fiéis.

É importante salientar que o uso da linguagem feito pelo bispo não se restringe apenas ao tipo religioso, mas também ao tipo político, como por exemplo, a reação aos ataques feitos pela imprensa a IURD, e ao tipo filosófico sendo que acaba por influenciar e conduzir a vida de muitas pessoas. Dessa forma, o discurso construído por meio do editorial caracterizou-se pelos métodos da persuasão. Assim sendo, vimos que o discurso de Edir Macedo no editorial utilizou-se principalmente da função emotiva (apresenta-se como símbolo "exemplo" de vitória), no entanto, não deixou de usar também metáforas e sintagmas cristalizados. 
Ciro Athayde Barros Monteiro, Oswaldo Francisco de Almeida Junior

A informação mediada no discurso de Edir Macedo: análise de editoriais da Folha Universal

\title{
4.4 Editorial: Mar de conquistas
}

O editorial da edição de $n^{\circ} 943$ foi uma mensagem do bispo Edir Macedo transmitido, diretamente de Londres por telões, a milhões de pessoas que estavam reunidas em todo o Brasil para o encontro do dia D de 21 de abril de 2010. Segundo o jornal, o encontro reuniu mais de 8 milhões de pessoas. Foi um dos maiores eventos feitos por uma instituição religiosa e o líder da IURD falou sobre a importância do encontro e de Deus na vida das pessoas:

\begin{abstract}
Jesus disse: "Porque, onde estiverem dois ou três reunidos em meu nome, ali estou no meio deles". Veja: nós estamos reunidos em grande número de pessoas. Deus não faz uma promessa qualquer, não é uma conversa qualquer. Eu tenho certeza de que Ele já está presente na vida daqueles que se encontram neste evento, não apenas nos lugares onde as pessoas estão concentradas, mas na vida dos que estão assistindo em casa, em seu palácio ou até mesmo em barraco. Deus está com você agora (MACEDO, 2010, p. 3i).
\end{abstract}

Percebe-se que o bispo se apropria de um discurso universal, ou seja, tenta envolver todos os tipos ou classes de pessoas em sua igreja. Fala tanto para quem está assistindo em um palácio como para quem está em um barraco. Outra questão interessante está na posição em que o sujeito discursivo (Edir Macedo) ocupou no enunciado. Falou para milhões de pessoas em telões simbolizando a voz divina em uma posição discursiva privilegiada. Dessa forma, diz o bispo:

Saiba que Deus está presente em sua vida: quando você está no fundo do poço, não pode contar com ninguém, nem familiares, colegas. Você fica só, somente com Deus ao seu lado. Tenho certeza de que você não vai sair da mesma forma que entrou, vai sentir algo diferente, pois o Deus dos impossíveis vai fazer algo. O que ele fez no passado irá realizar na sua vida nesta tarde. Todos nós somos capazes de errar, mas Deus não pode se dar ao luxo de falhar, pois Ele é Deus, perfeito. Deus está pronto para atender o clamor daqueles que o invocam na sinceridade. Ele diz: "Aquele que vier a mim de maneira nenhuma o lançarei fora". Aqui Ele inclui pessoas de todas as religiões, sejam católicos, evangélicos, espíritas (MACEDO, 2010, p. 3i).

É importante salientar que a ideia de fundo do poço apresentada pelo líder da IURD está vinculada a "Teologia da prosperidade" segundo a qual 
torna plausível o consumo inerente ao sistema capitalista vigente na sociedade brasileira. Dessa forma, o bispo utilizou o espaço do editorial neste número para transmitir mensagem aos fiéis impondo-se como voz divina, e aproveitou para afirmar a abertura da IURD para todas as pessoas e religiões.

\section{CONSIDERAÇÕES FINAIS}

A partir da definição da ideia de Informação Religiosa, da IURD como mais um elemento na concepção de espaço informacional que existe como ordenação do mundo e da realidade, e do desenvolvimento da ideia de Edir Macedo como mediador da informação, buscou-se compreender como a informação, principalmente a Informação Religiosa, é mediada no discurso de Edir Macedo.

A problemática central do estudo foi a de entender o funcionamento do discurso do líder da IURD, ou seja, as estratégias discursivas, o sujeito falante, as posições discursivas, as intenções do sujeito por meio de análise dos editoriais da Folha Universal e a mediação desses fatos - informação como construção da realidade para o leitor.

Respaldou-se sobre o aparato teórico da Análise do Discurso, ou seja, na ideia de discurso religioso, formação discursiva, discurso persuasivo e discurso ideológico que foram essenciais no processo de compreensão e análise dos editoriais, em que verificamos a presença desses sujeitos na construção do discurso do líder da IURD.

Por meio dos editoriais foi possível verificar que Edir Macedo utiliza-se prioritariamente do discurso persuasivo para construir seus enunciados. Dos quatro editorias analisados, a função emotiva esteve presente em sete, ou seja, o bispo apela à questão da fé, da salvação, e do Senhor como exemplo a ser seguido.

O uso da função emotiva apresentou Edir Macedo como modelo de conquista, vitória e superação. Criou-se como, por exemplo, no editorial Como esta data pode definir a sua vida, a imagem do líder como sendo um homem 
objetivo, confiante, trabalhador e ousado. Utilizou-se da imagem de homem preso - imagem da capa de sua biografia - como símbolo de injustiça.

O modo imperativo também teve amplamente utilizado em seu discurso. Esse modo aparece em vários momentos, como por exemplo, quando o líder afirma que "Todos os que crêem terão sua vida mudada" (MACEDO. Mar de conquistas. p. 3i), ou "Tenha certeza de que você não vai sair da mesma forma que entrou" (MACEDO, 2010, p. 3i).

O discurso ligado a Teologia da Prosperidade apareceu em dois editoriais, sendo eles: $A$ oferta nos torna merecedores e $A$ oferta abre caminhos, os quais fazem inúmeras referências a necessidade de doação a IURD. No entanto, é possível verificar que o discurso de Edir Macedo quase sempre traz um enunciado vinculado à doação de dízimos à IURD. Para o líder a demonstração de fé está associada à doação, sendo que ofertar à igreja significa ofertar a Deus.

O bispo fez uso excessivo de citações da bíblia que serve para afirmar, por meio da voz de Deus, o que o sujeito fala. Dessa forma, o sujeito fala em nome e como representante de Deus na terra. O que torna o discurso do dízimo como, por exemplo, o enunciado em "Sua vida é resultado da oferta que você coloca no altar" (MACEDO, 2010, p. 3i) um discurso de persuasão. O líder da IURD se apropria de um discurso universal que tenta envolver todos os tipos de classes e pessoas em sua igreja, e utiliza-se do espaço do editorial para servir de resposta as acusações de outras mídias a sua igreja ou para mostrar o poder dos seus meios de comunicação, por meio de publicação de relatos de grandes personalidades, principalmente políticas.

Verificou-se que o impressionante discurso de Edir Macedo se utiliza de estratégias discursivas ideológicas que faz comparações e trocas de palavras para conseguir maior adesão do público (MACEDO, 2010, p. 3i), se apropria de um discurso ecumênico, afirmando a abertura da igreja para todas as religiões.

Dessa maneira, averiguou-se que a Folha Universal e seus editoriais são importantes veículos de funcionamento do discurso do líder da IURD, sendo essenciais no processo de crescimento midiático da igreja, já que além de utilizar mecanismos de linguagens de persuasão, consegue atingir fiéis - 
leitores múltiplos, como por exemplo, presidiários, passageiros de ônibus, entre outros.

Por fim, percebe-se que a informação mediada nos enunciados de Edir Macedo, ou a ampla maioria dos discursos são de força persuasiva, fazendo com que os fiéis-leitores creiam no que é veiculado e executem ações, como por exemplo, praticar o dízimo, já que o bispo assume quase sempre a posição discursiva de representante de Deus, utilizando-se de citações da Bíblia, exemplos de conquistas materiais e apresenta-se como modelo de vitória.

Assim sendo, Edir Macedo, por meio da mediação da Informação Religiosa interfere de forma direta na vida dos indivíduos e da sociedade. Essa informação, que "[...] está imersa em ideologias e em nenhuma hipótese se apresenta desnuda de interesses" (ALMEIDA JÚNIOR, 2009, p. 93) é apropriada pelo fiel-leitor sendo responsável por formar opiniões e direcionar condutas de vida.

Foi possível visualizar as principais contribuições de um estudo vinculado à ideia de Informação Religiosa e da igreja como sendo mais um elemento na concepção de espaço informacional, trazendo novas problemáticas de estudo para o campo o que possibilita pensar a pesquisa como parte da construção do mundo e da realidade.

De modo geral e a partir da análise dos editoriais, conclui-se que a informação mediada nos enunciados do bispo tem as características do discurso persuasivo. Por meio da análise do discurso sabe-se que acreditar naquilo que se diz ou em quem diz algo depende muito da forma como se diz, ou seja, depende da maneira como o locutor põe a linguagem em funcionamento, especialmente a imagem que o locutor faz de si mesmo (TORRESAN, 2007).

Dessa maneira, Edir Macedo se utiliza das estratégias discursivas apontadas aqui para construir seu discurso, o que provavelmente seja responsável por influenciar um número amplo de pessoas fazendo com que a IURD, a cada dia, ganhe mais espaço na imprensa e na sociedade. 


\section{REFERÊNCIAS}

MACEDO, E. Folha Universal. Mensagem, Rio de Janeiro. 2009.

. A oferta nos torna merecedores -15 a 21 de nov. 2009.

. Como receber o Espírito Santo - 21 a 27 de mar. 2010.

. Como esta data pode definir a sua vida - 21 de abr. 2010.

. Mar de conquistas -02 a 08 de mai. 2010.

AGAMBEN, G. O que é o contemporâneo? e outros ensaios. Tradução Vinicius Nicastro Honesko. Chapecó, SC: Argos, 2009.

ALMEIDA JÚNIOR, O. F. de. Mediação da informação e múltiplas linguagens. Pesq. bras. Ci. Inf., Brasília, v.2, n.1, p.89-103, jan./dez.2009.

Profissional bibliotecário: um pacto com o excludente. In: BAPTISTA, S. G.; MUELLER, S. P. M. (Org.). Profissional da informação: o espaço de trabalho. Brasília: Thesaurus Editora, 2004b. p. 70-86.

BARROS, M.H.T.C. de. O professor como mediador da informação. In:

BARROS, M. H. T. C. de; SILVA, R. J. da, BORTOLIN, S. (Orgs.). Leitura: mediação e mediador. São Paulo: Ed. FA, 2006.

BERGER, P. L. O dossel sagrado: elementos para uma teoria sociológica da religião. São Paulo: Ed. Paulinas, 1985.

BERGER, P. L.; LUCKMANN, T. A construção social da realidade: tratado de sociologia do conhecimento. Petrópolis: Vozes, 1985.

CITELLI, A. Linguagem e persuasão. 16 ed. São Paulo: Ática, 2007.

CONESA, F; NUBIOLA, J. Filosofía del lenguaje. Barcelona: Herder, 2002.

DAVALLON, J. A mediação: a comunicação em processo? Prisma - Revista de Ciência da Informação e da Comunicação, Porto, n. 4, p. 03-36, jun. 2007, Disponível em: <http://prisma.cetac.up.pt/A_mediação_a_comunicação_em_processo.pdf>. Acesso em: 2 abr. 2013.

ELIADE, M. O sagrado e o profano. São Paulo: Martins Fontes, 1992.

FOUCAULT, M. Arqueologia do saber. Tradução de Luiz Felipe Baeta Neves. 7. ed. Rio de Janeiro: Forense Universitária, 2009. 
GREGOLIN, M. R. Foucault e Pecheux na construção da análise do discurso: diálogos e duelos. São Carlos: Clara Luz, 2004.

INSTITUTO PRÓ-LIVRO. Retratos da leitura no Brasil: realização. 3. ed. São Paulo: Ibope Inteligência, [2011]. Disponível em: $<$ http://prolivro.org.br/home/images/relatorios_boletins/3_ed_pesquisa_retratos _leitura_IPL.pdf>. Acesso em: 21 jan. 2015.

LE COADIC, Y. F. A Ciência da informação. Brasília: Brinquet de Lemos, 1996. 119p.

MARIANO, R. Expansão pentecostal no Brasil: o caso da Igreja Universal. Estudos Avançados. São Paulo. v.18, n.52, p. 121-138, dez. 2004. Disponível em: $<$ http://www.scielo.br/scielo.php?pid=S010340142004000300010\&script=sci_arttext>. Acesso em: 24.ago.2014.

MOSTAFA, S. P.; LIMA, A.B. de; MARANON, E.I.M. Paradigmas teóricos da Biblioteconomia e Ciência da Informação. Ci. Inf., Brasília, v.21, n. 3, p. 216 222, set/dez.1992.

ORLANDI, E. P. Análise do discurso: princípios e procedimentos. 5.ed. Campinas, SP: Pontes, 2003.

Silêncio e implícito: produzindo a monofonia. IN: GUIMARÃES, E. (Org.). História e sentido na linguagem. Campinas: Pontes Editores, 1989.

PINHEIRO, L. N. V. R.; LOUREIRO, J. M. M. Traçados e limites da ciência da informação. Ciência da Informação, v. 24, n. 1, p. 42-53, 1995. Disponível em: <http://basessibi.c3sl.ufpr.br/brapci/v/a/806>. Acesso em: 16 Mar. 2014.

PINHEIRO, L. V. R. Informação- esse obscuro objeto da Ciência da informação. MORPHEUS - Revista Eletrônica em Ciências Humanas: conhecimento e sociedade. Rio de Janeiro: UNIRIO. Coordenadoria de Educação a Distância, v. 2, n. 4, 2004. Disponível em: <http://www.unirio.br/cead/morpheus/numerosantigos.htm>. Acesso em: 25 jul. 2014.

SILVA; R. T. et al. Igreja Universal do Reino de Deus: a regionalização da fé em Uberlândia - MG. In: II SIMPÓSIO REGIONAL DE GEOGRAFIA "PERSPECTIVAS PARA O CERRADO NO SÉCULO XXI", 9, 2003, Uberlândia. Anais... Uberlândi,: UFU, 2003. Disponível em: $<$ http://www.academia.edu/14969329/Igreja_Universal_do_Reino_de_Deus_a_ regionaliza\%C3\%A7\%C3\%A3o_da_f\%C3\%A9_em_Uberl\%C3\%A2ndia_MG_>. Acesso em: 2 jan 2015. 
TAVALARO, D. O bispo: a história revelada de Edir Macedo com reportagem de Christina Lemos. São Paulo: Editora Larousse do Brasil, 2007.

TORRESAN, J. L. A manipulação no discurso religioso. Dialogia, São Paulo, v. 6, p. 95-105, 2007.

. O ponto de vista enunciativo sobre a linguagem: a modalização no discurso da Igreja Universal do Reino de Deus. Dialogia, São Paulo, v.3, p. 87103, out. 2004.

ZILLES, U. Religiões: crenças e crendices. 2. ed. Porto Alegre: EDIPUCRS, 1998.

\title{
Title
}

The mediated information in speech Macedo Edir: analysis of publishers of Universal Leaf.

\begin{abstract}
Introduction: The information mediated in the speech of Edir Macedo remains in prominent position in front of the transformations of contemporary society. The study proposed to analyze the strategies used in his speech to mediate information through the editorial of the newspaper Folha Universal (FU), the journal of the "Igreja Universal do Reino de Deus (IURD). Objective: To know the discursive strategies used by Edir Macedo in order to understand how this information is mediated and how can expand its influence daily turning it into one of the major mediators of Brazil. Methodology: Four editorials were selected writings of newspaper between 2009 and 2011, use of Discourse Analysis methodology. Results: The editorials analyzed show that the bishop uses primarily persuasive speech to get public support by appealing almost always emotional function and the imperative mood. Conclusions: We highlight the need for $\mathrm{Cl}$ to understand this discourse, since this information is responsible for influencing a large number of people making the IURD, every day, expand its space in the press and society.
\end{abstract}

Keywords: Edir Macedo. Mediation Information. Speech analysis. Universal Leaf.

\section{Titulo}

La información mediada en el habla macedo edir: análisis de los editores de Hoja de Universal

\section{Resumen}

Introducción: La información mediada en el habla Edir Macedo sigue siendo prominente posición por delante de las transformaciones de la sociedad contemporánea. El estudio tuvo como objetivo analizar las estrategias utilizadas en su discurso para mediar la información a través de la redacción de la "Folha Universal" (FU), el periódico de la "Igreja Universal do Reino de Deus" (IURD). Objetivo: Conocer las estrategias discursivas utilizadas por Macedo con el fin de entender cómo está 
Ciro Athayde Barros Monteiro, Oswaldo Francisco de Almeida Junior A informação mediada no discurso de Edir Macedo: análise de editoriais da Folha Universal

mediada esta información y cómo puede expandir su influencia diaria convirtiéndose en uno de los principales mediadores de Brasil. Metodología: editoriales de los periódicos se seleccionaron cuatro escritos entre 2009 y 2011, el uso de la metodología de análisis del discurso. Resultados: El editorial analizados muestran que el obispo se utiliza sobre todo discurso persuasivo para conseguir el apoyo del público apelando casi siempre la función emocional y el modo imperativo. Conclusiones: Hizo hincapié en la necesidad de $\mathrm{Cl}$ para entender este discurso, ya que esta información es responsable de influir en un gran número de personas que hacen la IURD, todos los días, puede ampliar su espacio en la prensa y la sociedad.

Palabras clave: Edir Macedo. Información de la mediación. Análisis del Discurso. Universal Leaf.

Recebido: 12.02 .2016

Aceito: 25.03.2017 